\title{
PUBLIC POLICIES ON WATER RESOURCES FOR THE BRAZILIAN NORTHEASTERN SEMIARID REGION
}

Pedro Henrique da Silva Lima (https://orcid.org/0000-0002-6363-4671) ${ }^{1}$, pedroh079@ hotmail.com Maria Losangela Martins de Sousa (https://orcid.org/0000-0003-3798-283X) ${ }^{1}$, mariasousa@ uern.br Larissa da Silva Ferreira Alves (https://orcid.org/0000-0003-2232-9539) ${ }^{1}$, larissaferreira@ uern.br José Elesbão de Almeida (https://orcid.org/0000-0002-9411-7300) ${ }^{1}$, elesbaoalmeida@uern.br

1 State University of Rio Grande do Norte, 59900-000, Pau dos Ferros - RN, Brazil

Submitted: 19/02/2021. Accepted: 21/05/2021

Published: 27/05/2021

\begin{abstract}
Objective: The present study has as main objective to identify the strategies taken by the municipal managers to adapt to the periods of greatest water difficulties in the northeastern semiarid, more specifically in the city of Doutor Severiano-RN, showing the importance of the development of these strategies in the region.
\end{abstract}

Methodology / Approach: Research were made on the subject to identify which strategies were developed in the municipality, in addition, some field observations were made to identify the municipal public policies developed over the years.

Conclusions: It is concluded with this study that it is essential to know the place and seek the best strategy to develop and apply these policies based on the characteristics of each region, considering the importance that they have for the social and economic development of the semiarid populations.

Research limitations: The sample was extracted from works that addressed the topic in question, thus making the parallel of discourse between theory and practice.

Originality / Value of the article: The study presents the strategies developed in the city of Doutor Severiano, to adapt to the periods of greatest water difficulties in the region, according to the climatic conditions of the place.

Keywords: strategies, development, resources, water, climate.

\section{POLÍTICAS PÚBLICAS DE RECURSOS HÍDRICOS PARA O SEMIÁRIDO NORDESTINO BRASILEIRO}

\section{RESUMO}

Objetivo: O presente estudo tem como principal objetivo identificar as estratégias tomadas pelos gestores municipais para adaptação aos períodos de maiores dificuldades hídricas no semiárido nordestino, mais especificamente no município de Doutor Severiano- RN, apresentando a importância do desenvolvimento destas estratégias na região.

Metodologia/Abordagem: Pesquisas foram realizadas para identificar quais as estratégias desenvolvidas no município, além disso foram feitas algumas observações de campo para identificar as políticas públicas municipais desenvolvidas ao longo dos anos.

Conclusões: Conclui-se com este estudo que é essencial conhecer o local e buscar a melhor estratégia para se desenvolver e aplicar essas políticas a partir das características de cada região, considerando a importância que as mesmas têm para o desenvolvimento social e econômico das populações semiáridas.

Limitações da pesquisa: A amostra foi extraída de obras que abordassem o tema em questão, fazendo assim o paralelo de discursão entre a teoria e a prática.

Originalidade/Valor do artigo: O estudo apresenta as estratégias desenvolvidas no município de Doutor Severiano, para se adaptar aos períodos de maiores dificuldades hídricas na região, mediante as condições climáticas do local.

Palavras chave: estratégias, desenvolvimento, recursos, água, clima. 


\section{INTRODUCTION}

The conception of public policies for the northeastern semiarid region is extremely important for the economic and social development of the population (Dantas et al., 2020; Palmeira et al., 2020; Ledru et al., 2020). Due to the region's semiarid climate, water difficulties are recurrent (Shubo, 2020; Teixeira et al., 2021) and the population needs support to adapt to these difficulties in the period. It makes it necessary to develop strategies. In this article, the main strategies developed throughout history in Northeast Brazil will be discussed, more specifically in the city of Doutor Severiano, thus presenting the importance of these policies for the social and economic development of the population.

Throughout history, the semi-arid climate in the Northeast has specific characteristics, suffering at times of the year with water unavailability, which according to Silva et al. (2011) occurs precisely because of the climatic characteristics of the northeast, as the semi-arid regions have, as main characteristic, irregular rains, varying spatially and from one year to another, as for example irregular rains occur during the first six months and in the rest of the year do not happen, thus making it difficult for the population to collect water. In the meantime, it is important to note that in much of the Northeast rain is the main means of supplying the population, which is exactly why the development of strategies that can adapt to these periods is essential for the backcountry population, due to the difficulties encountered in the climate of the region.

The development of public policies designed for and adaptable to the region is evident in the city of Doutor Severiano, located in the interior of Rio Grande do Norte (RN), which is the scope of this research (Alves et al., 2018; Silva et al., 2021). Due to the semiarid climate that presents high temperatures and therefore produces higher evapotranspiration levels than rainfall levels, strategies were developed in the city such as the construction of dams and weirs to capture rainwater, as well as other auxiliary methods such as cistern construction and installation, and the use of groundwater, mainly through well drilling.

Using public policies to adapt to periods of water shortage is one of the strategies taken by governmental entities. With this, the following questions arose to be discussed in this research: which strategies have already been developed and applied in the northeastern semiarid region to solve the problems caused by drought? What positive and negative points does the development of these policies bring to society? And which of these strategies were applied in the city of Doutor Severiano - RN?

This research has as main objective to identify the strategies taken to adapt to the periods of greatest water shortage in the northeastern semiarid region, more specifically in the city of Doutor Severiano - RN. To obtain this result, the following steps were taken: listing the main public 
policies developed over the years; presenting the positive and negative points of the strategies to adapt to the semiarid climate; and pointing out the strategies and results of these public policies in the city of Doutor Severiano.

This article is characterized as analytical, thus presenting an analysis in relation to the water resources of the city of Doutor Severiano, based on a bibliographic and geocartographic survey, with the addition of a field research to have information about the strategies developed, and with this discuss the results, from the surveys obtained.

\section{LITERATURE REVIEW}

\subsection{Public policies developed over the years in the northeastern semiarid region}

Public policies, according to Campos (2014), can be defined as actions and practices undertaken as functions of the State by a government seeking to solve general and specific issues of society. In the context of the semiarid region, public policies on droughts only began after the government recognized them as a national problem and acted to solve them. Still according to Campos (2014), this only happened with the tragedy and worldwide repercussion of the Great Drought from 1877 to 1879 , when hundreds of thousands of people died. From then on they started to look for strategies to adapt to the periods of greatest water shortage in the region.

Within this scenario of changes in the search for strategies to mitigate the impacts caused by water crises, the role of the State arises. As claimed by Falcón (2014), the State can and should strategically plan development according to the location and the situation, with policies appropriate to the economic and social dynamics at each historical moment.

According to Cardoso (2018), public policies are solution providers and are seen as means to mitigate the socio-environmental impact caused by this climatic phenomenon in the Northeast region. Because of it, it is necessary to elaborate assistance policies so that access to these resources becomes possible, as they are indispensable for human survival.

With this, according to Santos (2019), the State changes its way of thinking and acting, replacing its ideology of combating drought to give rise to the perspective of coexistence with the semiarid, based on the claim of social movements that fought for more equal conditions of water distribution. However, even with this change of vision about drought, the favoring of people with greater purchasing power continued and they would take advantage of the situation in which the poorest found themselves. It came to fruition right at the beginning of the development of the first public policies to adapt to drier periods, such as the weir strategy. Such method consisted in the construction of large weirs to collect water and supply the population. However, the main 
beneficiaries of these constructions were the traditional oligarchic groups, as these weirs were built within their properties, and thus used these waters as a bargaining chip, to influence who needed the resource (Santos, 2019).

Continuing the development of strategies to adapt to droughts, after the weirs came the construction of the dams, but they continued to benefit even more the large landowners. Santos (2019) highlights from his studies that it was only between 1902 and 1906 that the first official steps were taken to create a safe scheme in the northeastern semiarid of a hydraulic structure. It aimed at mitigating the effects caused by the periods of greater water shortage and resulted in the creation of three commissions. The first was made up of weirs and irrigation, followed by studies and works against the effects of droughts, and finally the use of wells. But even after the creation of this plan, these strategies still lived in apathy, as what had been planned was not put into practice.

It was from this that the first federal agency for regional intervention was created, the Inspectorate of Works Against Droughts (IOCS) in 1909. It was created to put into practice the strategies thought to alleviate the problems caused by droughts. In 1945 the IOCS changed its name to the National Department of Works Against Drought (DNOCS), having even more agility and resources for the construction of physical works in the semiarid region (Santos, 2019; Carvalho, 2018).

Another strategy thought and developed to deal with water shortage in the semiarid northeast region was the construction of plate cisterns. According to Santos (2019), plate cisterns have become an efficient and viable alternative, as they have low construction and maintenance costs. These cisterns make it possible to capture water from house roofs in rainy seasons by installing pipes and a reservoir with the capacity to store water. This resource has great utility for families, as they can have good quality water stored and use it for various purposes, such as domestic or agricultural.

Over the years, cisterns have undergone a transformation. The plate cisterns, built close to homes, have been replaced by cisterns commonly known as plastic (polyethylene) cisterns. According to Santos (2019), this change was due to the fact that these plastic cisterns enabled mobility to be relocated. Another determining factor was the change in government posture that started to adopt plastic cisterns instead of plate cisterns.

All these strategies developed in the northeastern semiarid region become possible and successful based on the adaptation of the population to them. This adaptation is confirmed in the statements of Carvalho (2014), in which he cites the great response capacity of the semiarid population for coexistence with the drought phenomenon. This coexistence is of fundamental importance for the northeastern regional development. 
Another strategy developed in the semiarid northeast region that deserves to be highlighted, because of its relevance for the development of the region, is the drilling of wells that may have some variations in their forms. Some of them are called "cacimbas", others artesian and semiartesian wells, or even excavated wells. They have these different nomenclatures because they vary in the way they withdraw water and the way they are built. The importance of these groundwater wells is confirmed by Cirilo (2008), who mentions the drilling of wells for using this groundwater as part of the supply policy of this semiarid region. It participates in the supply of rural communities in the Northeastern semiarid, of the urban population of several cities in northeastern, whether in irrigation, agriculture, livestock, domestic use, and other applications.

In addition, the use of groundwater also generates other forms of water distribution, as the distribution strategy based on water tank trucks. According to Campos (2014), the presence of water tank trucks as a source of water supply is constant in the second semester of the year in the Brazilian semiarid region. Due to the climatic conditions, the region has in the six last months of the year the greatest water shortage, which makes water transfer from water tank trucks one of the strategies taken in the quest to alleviate the difficulties.

An important point in the development of these public policies for the semiarid region is the knowledge of the place where the strategies will be developed. It is necessary to have prior knowledge of the place to think about strategies according to the needs of each one. It is in this perspective that Falcón (2014) cites the importance of popular participation in strategic decisions for the development process, as the population has better knowledge and experience of the place where the public policy will be applied.

The management of these water resources, according to Sobreira Neto (2019), must take place in a decentralized manner, counting on the participation of public authorities, users, and communities, and seeking to guarantee access to natural resources in an equivalent and sustainable way for all.

Based on the discussions by Silva (2018), according to the 1988 Federal Constitution, municipalities are obliged to set up their basic sanitation plans as a development instrument since it generates well-being for the population. It makes clear the government's responsibility to exercise its function and develop a plan that meets the needs of all inhabitants.

Regarding the development of these public policies and relating to the laws surrounding this theme, discussions can be based on Law No. 9,433 / 97 of the National Water Policy that institutes the National Water Resources Policy, in addition to creating the National Water System. Water Resources Management and other provisions. The legislation in question shows that water must be recognized as a public domain good (item I, art. 1 of Law 9.433), but also shows that its 
management and administration will be the responsibility of the Union and the States, leaving the municipalities to mission of implementing public policies that better treat and distribute this water resource. In this study the management of water resources in the city of Doutor Severiano is done autonomously through the Autonomous System of Águas de Esgotos, according to the municipal management.

\subsection{Positive and negative points of the strategies developed to adapt to the semiarid climate}

According to Araujo (2018), the problems related to water scarcity in Brazil are getting worse over the last few years. Thereby, they are directly reflecting on the need to improve new water resources management practices from the economic, social, and economic aspects, thus seeking to develop strategies to adapt to this reality.

The development of public policies for adapting to droughts is a way of seeking to alleviate the problems and difficulties of the population of the Brazilian semiarid region. The strategies developed in these policies have positive and negative points regarding their applicability in the face of the varied scenarios of the Northeast region.

Based on this, the positive points found to be discussed in this research are the following: The first fits within the perspective of development in the Northeast, in which, according to Falcón (2014), the importance of these public policies is proven from the moment that migration from the Northeast to other regions decreases. This happens because, with the development of the region, it is possible to live with droughts, due to the various strategies developed to alleviate water difficulties.

The development of these policies also enables the population with less purchasing power to maintain themselves during water crises. Many families depend on water to support their families through agriculture and livestock. It also helps to continue the economic and social development of the population. In addition, as it is a public work, it gives access to the needy and benefits all families, thus seeking to reduce the concentration of water power in the hands of a few.

Santos (2019) highlights some negative points within these developed policies, and the first to be highlighted is the construction of public weirs that were carried out predominantly within the colonels' farms, and the water in those reservoirs was primarily used for their herds. In the meantime, the rest of the population who should have the right to use this resource only had access to the water in rare cases of "kindness" by these colonels.

According to Santos (2019), the disasters that resulted from the drought that occurred between 1991-1993, such as plundering, irreparable losses in fields, death of animals, and the migration of the population to other places in search of better living conditions, evidenced the 
insufficiencies of the public policies to "combat drought". It was from that moment on that strategies started to be thought adaptable to the place where they would be applied, thus seeking to know different scales in the search for strategies of coexistence with the semiarid region.

Another difficulty encountered in the development of such public policies was their applicability to the population, as they often did not reach the scenarios that were promised or needed. Thus, Santos (2019) emphasizes the difficulties of distribution using water tank trucks since the trucks did not have access to a specific location and thus deposited the water at specific points of the municipality. As a result, part of the population found it difficult to move to these places to collect water.

It is also worth mentioning the practice of drilling wells that in many cases are drilled on private properties and, as a result, access by the population is restricted by orders from the owner of the property, with the same phenomenon occurring when the weirs were drilled within the territories of the colonels.

\section{MATERIALS AND METHODS}

This study was developed through bibliographic research that detected which strategies were developed in the region to alleviate water scarcity, as well as a field research that made it possible to identify which public policies were developed in the city of Doutor Severiano.

It is important to emphasize that this study presents a qualitative approach, this approach is characterized from the readings and analysis made on the theme, coming to identify the main points to be discussed during the work, such as the successes and the mistakes in the development of policies as well as the strategies developed in the periods of greatest water difficulties in the region.

In the development of this study, three sections were used: (I) bibliographic and geocartographic survey; (II) field research, to obtain information about the strategies developed, based on observations and analysis; (III) Analysis and discussion of the results obtained in the previous sections.

\subsection{Study area}

This research has as study area the city of Doutor Severiano, belonging to the state of Rio Grande do Norte, located in the northeastern region of Brazil (figure 1). The municipality in question is located in the microregion of the Serra de São Miguel, bordering on the east with the municipality of Encanto, on the south with the municipality of São Miguel, and on the west and north bordering the State of Ceará, covering an area of area of $113.737 \mathrm{~km}^{2}$ according to the IBGE (2010). Regarding the population data of the municipality, according to the demographic census of the IBGE 2010, it had 6,492 people, being 3,193 men and 3,299 women, in addition with 
approximately $57 \%$ residing in the rural area and $43 \%$ in the urban area of the municipality. However, currently according to the IBGE, the municipality has an estimated population of 7,076 people (Ibge, 2010).

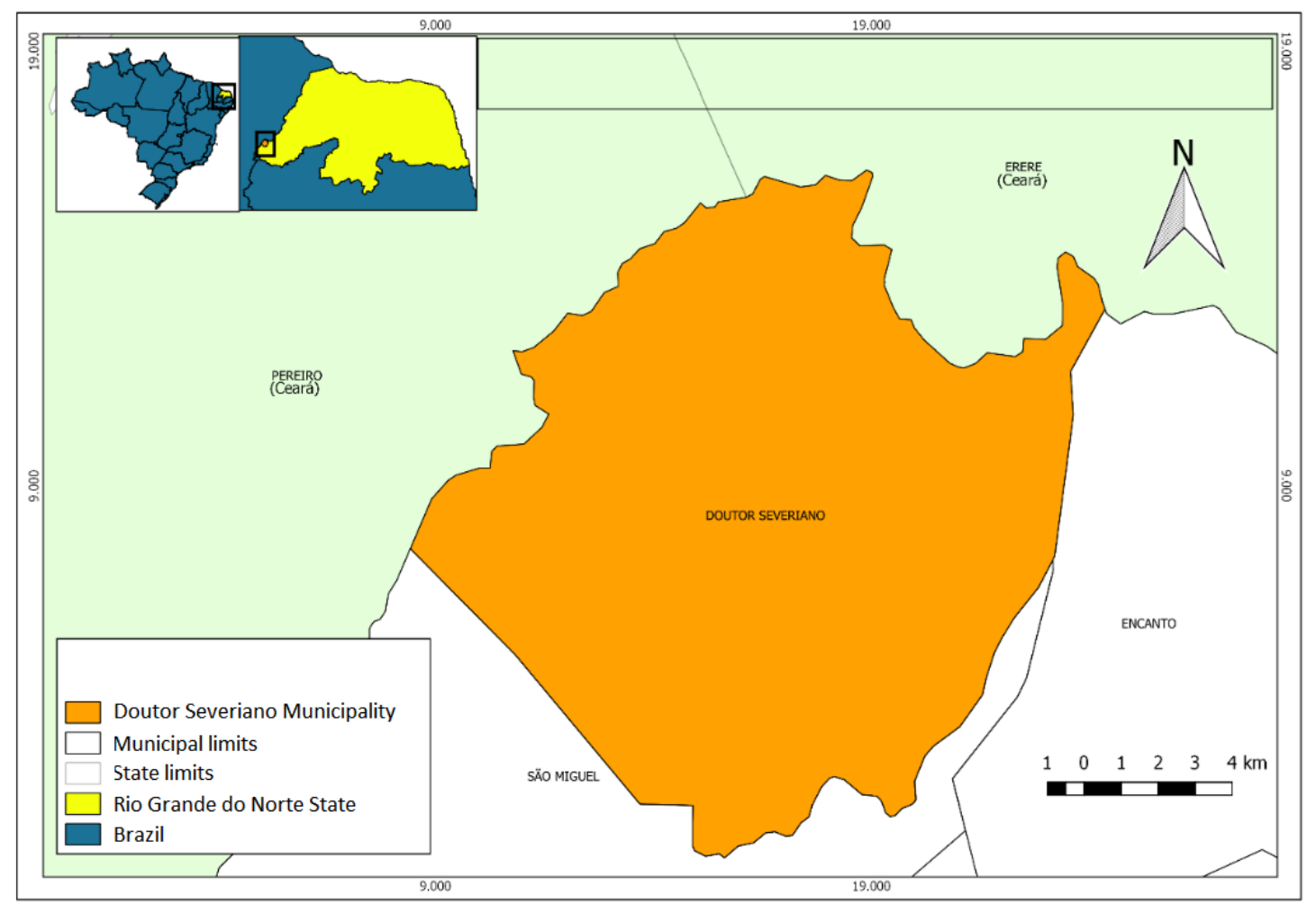

Figure 1 - Location map of the municipality of Doutor Severiano - RN (Brazil)

Source: Author (2020)

\subsection{Data collection instruments}

Data collection took place from bibliographic readings on the subject in question in internet databases. Regarding field research, field notebooks were used for annotation and the photographic record was made from a cell phone.

\subsection{Data collection procedures}

Data collection followed each stage of research development, following the objectives presented. Thus, the bibliographic survey provided important publications that deal with the theme addressed, and from that, readings and selection of texts that would be worked on in the research were carried out. The field research data were obtained from observations in the territory of the municipality. 


\section{RESULTS AND DISCUSSIONS}

\subsection{Results of public policies on drought adaptation implemented in the city of Doutor Severiano}

In the city of Doutor Severiano, several strategies have been developed over the years to adapt to the periods of greatest water crises due to the semiarid climate of the region. Among these strategies are the use of weirs to supply the entire municipal population, well drilling and use of groundwater, and construction of plate cisterns, or use of "plastic" cisterns to capture rainwater and supply by water tank trucks that transport water from other cities to Doutor Severiano. These alternatives can be seen in Figure 2, which contains five images referring to the types of strategies taken in the municipality.

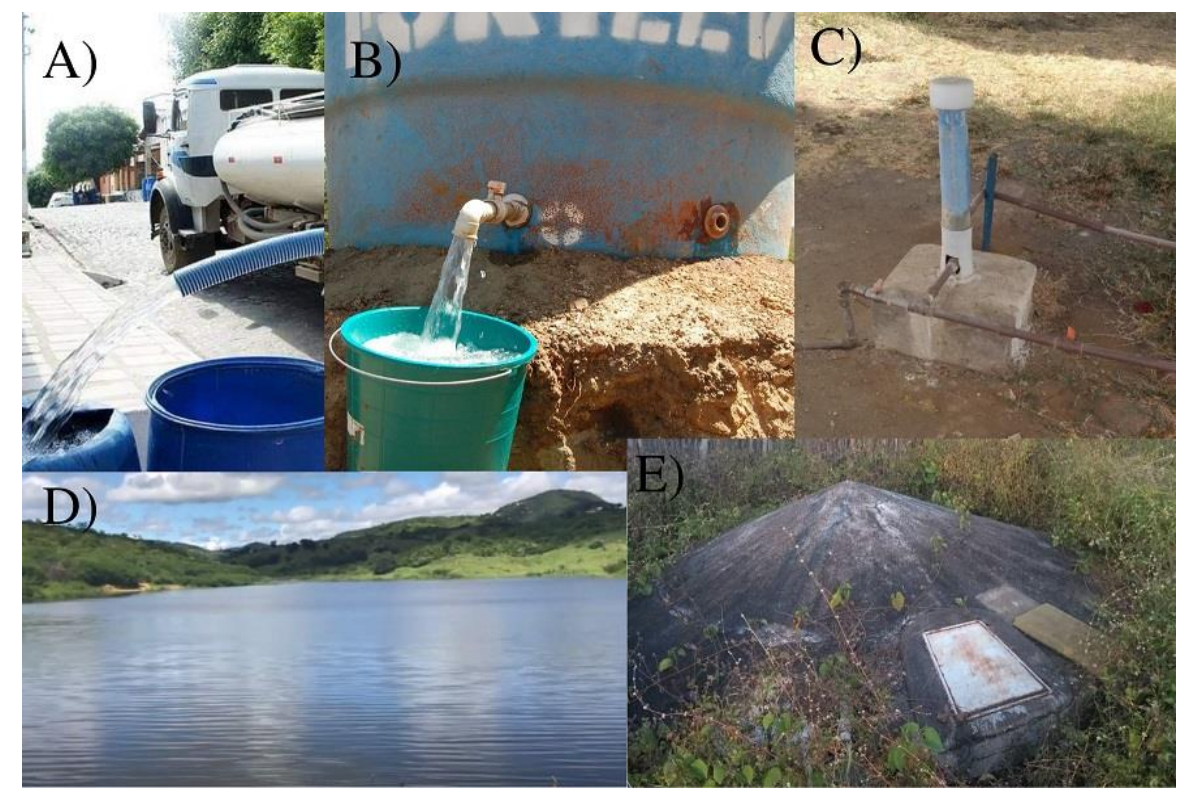

Figure 2 - Images referring to the strategies taken in the city of Doutor Severiano- RN

Source: Images A and B of the personal profile of photographer Edson Silva from the municipality of Doutor Severiano on Facebook. Images C, D and E personal file (Field research).

In Figure 2, it is possible to identify four activities developed in the city of Doutor Severiano, which are divided into five images. Image "A" corresponds to the use of water tank trucks in the municipality, and image "B" shows the removal of these waters from the blue boxes filled by the water tank trucks. In image " $C$ " is the representation of a well drilled in the municipality and another public policy strategy developed. In image " $\mathrm{D}$ " there is a photo of one of the main reservoirs of the city. It is located in the rural area, at Sítio Merejo, and is responsible for supplying the entire urban area and a large part of the rural area. Finally, image "E" is a cistern, a strategy widely used, especially in rural areas. 
The first highlight is the construction of the reservoirs in the municipality. This activity started in the 1980s, with the construction of the Vassourinha I reservoir, and has become the main source of supply for the population, with emphasis on the reservoir of Sítio Merejo shown in Figure 2 (image "D"). This reservoir, along with Vassourinha I, is mainly responsible for supplying the population of the entire municipality from a water distribution facility. In addition, it is also worth mentioning the weirs of Trincheira and Sítio Vassourinha II, which aid in supplying the population but still play an important role, especially for residents close to the locations of the weirs. These reservoirs are located within the territory of the municipality and, according to IDEMA (2008), have an accumulation capacity greater than $1,000,000 \mathrm{~m}^{3}$.

The policy for the construction of cisterns was a strategy developed throughout all the territory of Rio Grande do Norte, which according to Femurn (2020), covered more than 50 municipalities, and among these was Doctor Severiano. The cisterns were built on the city farms, in almost all the houses of its residents. It is possible to see and identify the use of this resource in Figure 2 (image "E"). The first cisterns were built in the municipality in the 1990s. However, it was between the years 2012 and 2014 that this strategy had its greatest number of constructions due to the great water shortage that the population went through during this period.

According to Santos (2019), the fact that these cisterns have a low production cost and many benefits, governmental organizations saw this activity as a concrete opportunity to alleviate the region's water difficulties. The cisterns were built to serve as an aid to the population, capturing water and storing it for when necessary, whether for domestic use or in agriculture.

Concerning the use of underground water to supply the population, the highlight is the use of well drilling, the most used practice within the municipality. Including private and public wells, the city has a significant amount of drilling. The high number of wells drilled in the municipality reached its peak in 2013, during a water crisis, where the population and the municipal government saw the drilling of wells as an alternative to meet the needs of the population.

According to IDEMA (2008), the drilled wells have a low average flow rate of $3.05 \mathrm{~m} / \mathrm{h}$ and a depth of up to $60 \mathrm{~m}$ on average and commonly with water. In addition, some of them had a high salt content, largely because of the location where they were drilled, but not sufficient to be necessary to desalinate the water.

The public wells drilled in the municipality serve as auxiliaries for supplying the population, because in periods when the weirs have a low level of stored water, the wells must supply water to the population. In Figure 2 (image "C"), it is possible to identify one of these public wells. According to Silva Júnior et al. (2018), it is due to the importance highlighted above that 
government officials see in these wells ways to provide a better quality of life to the population seeking to meet the needs of all.

Finally, there is also the public policy on the use of water tank trucks. This strategy was also planned and developed during the water difficulties of the years 2012 and 2013. It consisted of transporting water from the municipality of Apodi - RN to Doutor Severiano. When they arrived at their destination, they were dumped in plastic (polyethylene) water tanks of up to 3,000 liters, as shown in Figure 2 (images "A" and "B"). The population would move to where the boxes were and remove the water and then transport it to their homes.

In the urban area of the city, boxes were installed at strategic points on each street, and at points that would facilitate access and removal of water. In the rural area, these boxes were also placed at strategic points to facilitate the removal of water by most of the population. Each person would transport the water to their homes, either with the help of animals or with buckets placed in wheelbarrows. This strategy is still used today, but at a lower frequency, compared to the initial years. Campos (2014) highlights these strategies due to the adverse climatic conditions of the region. The author points out that the climate causes water vulnerabilities, and therefore, it is necessary to develop multiple strategies for adapting to the semiarid climate.

\section{CONCLUSION}

It is concluded from this study that the development of water policies designed and planned is critical for social development and the quality of life of populations living in areas where obtaining it difficulties are greater. Therefore, these strategies developed to adapt to the semiarid climate become something that should always be on the agenda in the search for improvements and advances in the social development of the population.

This research also presented the public policies developed over the years, thus showing its historical importance over time, in addition to presenting the main positive and negative points in the planning of these strategies. It was found the importance of knowing the place where these activities are carried out, in order to obtain more success in the execution of the planned plans.

Finally, it is possible to note the great relevance that public policy planning has for the municipality of Doutor Severiano, in which the use of the developed strategies is of considerable importance for the well-being of the population in periods of low water availability.

The recommendation for future studies is to understand the reality of the place where you are studying, according to the theme proposed in the research. Thus, presenting the vision of the civilian population and local government, in addition to presenting the climatic conditions of the 
place and what strategies would be necessary to adapt to this phenomenon, and with that to evidence which are the best strategies to alleviate the water difficulties.

\section{REFERENCES}

Alves, L. D. S. F., Dantas, J. R. D. Q., \& Souza, G. S. (2018). Dynamic urban-regional in internal frontier territories. Mercator-Revista de Geografia da UFC, 17 (2), 1-15. https://doi.org/10.4215/rm2018.e17003

Araujo, R. L. (2018). An analysis of the water crisis and the management of water resources in the Federal District. 2018. Course Conclusion Paper (Graduation in Civil Engineering) - Faculty of Technology and Applied Social Sciences, Centro Universitário de Brasília, Brasília, 2018.

Campos, J.N.B. (2014). Droughts and public policies in the semiarid: ideas, thinkers and periods. Advanced Studies, [s.l.], 28 (82), 65-88. https://doi.org/10.1590/s0103-40142014000300005

Cardoso, R. C. (2018). Public policies: an alternative to fight the water crisis in the semiarid region. 34f. Course Conclusion Paper: Higher Course in Technology in Public Management, Center for Sustainable Development in the Semiarid Region, Federal University of Campina Grande, Sumé - Paraíba - Brazil, 2018.

Carvalho, C.P.O. (2014). THE NEW GROWTH PATTERN IN THE SEMI-ARID NORTHEAST. Revista Econômica do Nordeste, 45 (3), 160-184.

Carvalho, C.P.O. (2018). The Development of the Northeast Region in the Post-Sudene Years (2000-2016). Revista Paranaense de Desenvolvimento, 39 (134), 21-36.

Cirilo, J. A. (2008). Public water resources policies for the semi-arid. Advanced Studies, 22 (63), 61-82. https://doi.org/10.1590/s0103-40142008000200005

Dantas, J. C., Silva, R. M., \& Santos, C. A. G. (2020). Drought impacts, social organization, and public policies in northeastern Brazil: a case study of the upper Paraíba River basin. Environmental monitoring and assessment, 192 (5), 1-21. https://doi.org/10.1007/s10661-020-8219-0

Falcón, M.L.O. (2014). State and regional planning: perspectives and obstacles to the development of the Northeast. In: GUIMARÃES, Paulo Ferraz (Org.). A territorial look at development: Northeast. Rio de Janeiro: National Bank for Economic and Social Development, p.244-275.

Femurn. Large northern river. (2020). More than 50 potiguares municipalities will benefit from cisterns. Available at: https://www.femurn.org.br/noticias/3059/mais-de-50-municpios-potiguares-sero-beneficiados-com-cisternas. Accessed on: 27 jul. 2020.

Ibge - Brazilian Institute of Geography and Statistics. Doctor Severiano: History of the city. 2010. Municipality of Doutor Severiano- RN, 1, 1 - 4.

Idema - INSTITUTE OF SUSTAINABLE DEVELOPMENT AND ENVIRONMENT OF RIO GRANDE DO NORTE. (2008). Profile of your municipality: Doutor Severiano. State Secretariat for the Environment and Water Resources Semarh, Natal, 10, 1-22.

Silva Júnior, I. R., Alves, L. D. S. F., \& Oliveira Pinto Filho, J. L. (2018). Water as a public social good: privatization processes in relation to public supply in Pau dos Ferros-RN. Geosul, 33 (68), 58-82. https://doi.org/10.5007/2177$\underline{5230.2018 \mathrm{v} 33 \mathrm{n} 68 \mathrm{p} 58}$

Ledru, M. P., Jeske-Pieruschka, V., Bremond, L., Develle, A. L., Sabatier, P., Martins, E. S. P. R., ... \& Araújo, F. S. (2020). When archives are missing, deciphering the effects of public policies and climate variability on the Brazilian semi-arid region using sediment core studies. Science of the Total Environment, 723, 137989. https://doi.org/10.1016/j.scitotenv.2020.137989

Palmeira, P. A., Araújo Mattos, R., Pérez-Escamilla, R., \& Salles-Costa, R. (2020). Multisectoral government programs and household food insecurity: evidence from a longitudinal study in the semiarid area of northeast, Brazil. Food Security, 1-14. https://doi.org/10.1007/s12571-020-01100-4

Santos, T. A. (2019). Political dilemmas for the Brazilian semi-arid region: a brief overview until the crisis of Lulism. Rev. Nera, 22 (46), 170-194. https://doi.org/10.47946/rnera.v0i46.5605

Shubo, T., Fernandes, L., \& Montenegro, S. G. (2020). An overview of managed aquifer recharge in Brazil. Water, 12 (4), 1072. https://doi.org/10.3390/w12041072 
Silva, F. E. (2020). Water supply - Protection. Doctor Severiano, 21 May 2016. Available at: https://www.facebook.com/edsonaerobica/media_set?set=a.821904627940366\&type=3.

Silva, G. S. J. (2018). Public water management policies, water security and the judicialization of conflicts related to access to water in Campina Grande / PB. 2018.153f. Dissertation (Postgraduate Program in Regional Development PPGDR) - State University of Paraíba, Campina Grande - PB.

Silva, R. C. D., Fonseca, M. A. P. D., \& Borges, A. L. M. (2021). Tourism and public investment management: an analysis in the tourism regions of rio grande do norte-brazil 2003/2016. Tourism: Vision and Action, 23 (1), $26-47$. https://doi.org/10.14210/rtva.v23n1.p26-47

Silva, V.P. R.; Pereira, E. R. R; Azevedo, P. V.; Sousa, F. A. S.; Sousa, I. F. (2011). Analysis of pluviometry and rainy days in the Northeast region of Brazil. Brazilian Journal of Agricultural and Environmental Engineering, 15 (2), 131 138. https://doi.org/10.1590/s1415-43662011000200004

Sobreira Neto, J. L. (2019). Water resource management in Crato 


\section{DECLARATION OF CONTRIBUTIONS TO THE ARTICLE - CRediT}

\begin{tabular}{|c|c|c|c|c|}
\hline ROLE & PLima & MSousa & LAlves & JAlmeida \\
\hline $\begin{array}{l}\text { Conceptualization - Ideas; formulation or evolution of overarching research goals and } \\
\text { aims. }\end{array}$ & $\mathrm{x}$ & $\mathrm{x}$ & $\mathrm{x}$ & $\mathrm{x}$ \\
\hline $\begin{array}{l}\text { Data curation - Management activities to annotate (produce metadata), scrub data and } \\
\text { maintain research data (including software code, where it is necessary for interpreting } \\
\text { the data itself) for initial use and later re-use. }\end{array}$ & $\mathrm{x}$ & $\mathrm{x}$ & $\mathrm{x}$ & $\mathrm{x}$ \\
\hline $\begin{array}{l}\text { Formal analysis - Application of statistical, mathematical, computational, or other } \\
\text { formal techniques to analyze or synthesize study data. }\end{array}$ & $\mathrm{x}$ & & & \\
\hline $\begin{array}{l}\text { Funding acquisition - Acquisition of the financial support for the project leading to } \\
\text { this publication. }\end{array}$ & $\mathrm{x}$ & & & \\
\hline $\begin{array}{l}\text { Investigation - Conducting a research and investigation process, specifically } \\
\text { performing the experiments, or data/evidence collection. }\end{array}$ & $\mathrm{x}$ & & & \\
\hline Methodology - Development or design of methodology; creation of models. & $\mathrm{x}$ & $\mathrm{x}$ & $\mathrm{x}$ & $\mathrm{x}$ \\
\hline $\begin{array}{l}\text { Project administration - Management and coordination responsibility for the research } \\
\text { activity planning and execution. }\end{array}$ & $\mathrm{x}$ & $\mathrm{x}$ & $\mathrm{x}$ & $\mathrm{x}$ \\
\hline $\begin{array}{l}\text { Resources - Provision of study materials, reagents, materials, patients, laboratory } \\
\text { samples, animals, instrumentation, computing resources, or other analysis tools. }\end{array}$ & $\mathrm{x}$ & & & \\
\hline \multicolumn{5}{|l|}{$\begin{array}{l}\text { Software - Programming, software development; designing computer programs; } \\
\text { implementation of the computer code and supporting algorithms; testing of existing } \\
\text { code components. }\end{array}$} \\
\hline $\begin{array}{l}\text { Supervision - Oversight and leadership responsibility for the research activity } \\
\text { planning and execution, including mentorship external to the core team. }\end{array}$ & & $\mathrm{X}$ & $\mathrm{x}$ & $\mathrm{X}$ \\
\hline $\begin{array}{l}\text { Validation - Verification, whether as a part of the activity or separate, of the overall } \\
\text { replication/reproducibility of results/experiments and other research outputs. }\end{array}$ & $\mathrm{X}$ & $\mathrm{X}$ & $\mathrm{X}$ & $\mathrm{X}$ \\
\hline $\begin{array}{l}\text { Visualization - Preparation, creation and/or presentation of the published work, } \\
\text { specifically visualization/data presentation. }\end{array}$ & $\mathrm{X}$ & & & \\
\hline $\begin{array}{l}\text { Writing - original draft - Preparation, creation and/or presentation of the published } \\
\text { work, specifically writing the initial draft (including substantive translation). }\end{array}$ & $\mathrm{x}$ & & & \\
\hline $\begin{array}{l}\text { Writing - review \& editing - Preparation, creation and/or presentation of the } \\
\text { published work by those from the original research group, specifically critical review, } \\
\text { commentary or revision - including pre- or post-publication stages. }\end{array}$ & $\mathrm{X}$ & $\mathrm{X}$ & $\mathrm{X}$ & $\mathrm{X}$ \\
\hline
\end{tabular}

